\title{
On the measurement of corporatism
}

Citation for published version (APA):

Cörvers, F., \& van Veen, A. P. (1995). On the measurement of corporatism. Researchcentrum voor Onderwijs en Arbeidsmarkt, Faculteit der Economische Wetenschappen. ROA Research Memoranda No. 1E https://doi.org/10.26481/umaror.199501E

Document status and date:

Published: 01/01/1995

DOI:

10.26481/umaror.199501E

Document Version:

Publisher's PDF, also known as Version of record

\section{Please check the document version of this publication:}

- A submitted manuscript is the version of the article upon submission and before peer-review. There can be important differences between the submitted version and the official published version of record.

People interested in the research are advised to contact the author for the final version of the publication, or visit the DOI to the publisher's website.

- The final author version and the galley proof are versions of the publication after peer review.

- The final published version features the final layout of the paper including the volume, issue and page numbers.

Link to publication

\footnotetext{
General rights rights.

- You may freely distribute the URL identifying the publication in the public portal. please follow below link for the End User Agreement:

www.umlib.nl/taverne-license

Take down policy

If you believe that this document breaches copyright please contact us at:

repository@maastrichtuniversity.nl

providing details and we will investigate your claim.
}

Copyright and moral rights for the publications made accessible in the public portal are retained by the authors and/or other copyright owners and it is a condition of accessing publications that users recognise and abide by the legal requirements associated with these

- Users may download and print one copy of any publication from the public portal for the purpose of private study or research.

- You may not further distribute the material or use it for any profit-making activity or commercial gain

If the publication is distributed under the terms of Article $25 \mathrm{fa}$ of the Dutch Copyright Act, indicated by the "Taverne" license above, 


\section{On the Measurement of Corporatism}

Frank Cörvers and Tom van Veen

ROA-RM-1995/1E

\footnotetext{
Frank Cörvers, Research Centre for Education and the Labour Market, University of Limburg; Tom van Veen, Faculty of Economics, University of Limurg, P.O. Box 616, 6200 MD Maastricht, The Netherlands. We thank Ruud Dorenbos for this computational assistance and his assistance in collecting the data.
}

Research Centre for Education and the Labour Market

Faculty of Economics and Business Administration University of Limburg

Maastricht, January 1995 


\section{CIP-GEGEVENS KONINKLIJKE BIBLIOTHEEK DEN HAAG}

Cörvers, Frank

On the measurement of corporatism / Frank Cörvers and Tom van Veen. - Maastricht : Research Centre for Education and the Labour Market, Faculty of Economics and Business Administration, University of Limburg. - (ROA-RM-1995/1E)

Met lit. opg.

ISBN 90-5321-152-7

Trefw.: corporatisme. 


\section{Inhoudsopgave}

\section{Page}

Abstract

1 Introduction

2 The concept of corporatism

3 The theory of corporatism 2

4 Empirical research: an overview 5

5 Can corporatism be measured on a one-dimensional scale? $\quad 8$

6 Results 10

7 Conclusions 17

$\begin{array}{ll}\text { References } & 18\end{array}$

$\begin{array}{ll}\text { Data appendix } & 21\end{array}$ 


\begin{abstract}
This paper discusses the question whether and how differences in economic performance are related to various forms of organization of labour relations: is there a relation between corporatism and economic performance? Next, the paper discusses the way in which corporatism is measured. Further, it is noticed that both in the theoretical and in the empirical analyses the role of the government is kept rather implicit. Therefore this paper aims to incorporate the government in a more explicit way into the analysis. The empirical analysis of the paper reveals that corporatist countries are not only characterized by centralization or coordination of wage bargaining, but also by relatively high government expenditures and tax revenues. Moreover, it is concluded that corporatist countries show a higher ratio of active to passive labour market policies and also show higher average unemployment benefits.
\end{abstract}





\section{Introduction}

After the two oil crises in the seventies, Western European economies had to adjust their economies to new economic developments. Adjustments were slow however, resulting in stagflation, with increasing inflation and increasing unemployment. This phenomenon, which contradicted the conclusions of the standard demand-oriented economic models, paved the way for increasing attention for the supply side of the economy. After the turbulent seventies, sharp differences in economic performance between countries, especially with regard to unemployment and inflation, showed up. This resulted in renewed attention for corporatism as a way to organize labour relations (Moene et al., 1992). Hence, the functioning of the labour market became an important research topic. The way in which wage bargaining is organized, in particular, gained a lot of attention. Is centralized wage bargaining to be preferred above decentralized wage bargaining?

The relevant question is whether and how differences in economic performance are related to various forms of organization of labour relations: is there a relation between corporatism and economic performance? In this paper, we will first discuss this question and the related empirical research. Next, we will discuss the way in which corporatism is measured. Is corporatism correctly measured by some indicator for coordination (Crouch, 1985 ) or centralization (Calmfors \& Driffill, 1988) of the labour relations and is it possible at all to measure corporatism by such a one-dimensional variable? Further, we notice that both in the theoretical and in the empirical analyses the role of the government is kept rather implicit. In this paper we aim to incorporate the government in a more explicit way into the analysis.

The paper is organized as follows. In the next section we discuss the concept of corporatism. In section 3 we present theoretical arguments for the existence of a relation between corporatism and economic performance. Section 4 gives a review of the main empirical results of cross-country research with regard to this relation. It turns out that corporatism moderates real wage rises and decreases unemployment, inflation and strike activity. Section 5 discusses some indicators that are not directly related to coordination or centralization but that could explain the success of corporatism for economic performance as well. In other words, is corporatism a one-dimensional variable? Section 6 presents the results of our empirical research on that question. Section 7 ends with the conclusions. 


\section{The concept of corporatism}

In a corporatist society, pressure groups discuss relevant topics with their counterparts. For example, consumers' organizations can discuss environmental matters with organizations of producers. On the labour market, unions and employers' organizations negotiate about the wage rate and discuss employment policies. Moreover, the government participates in the discussion and the negotiations are highly centralized. The aim of this kind of negotiation is often the conclusion of a central agreement, giving guidelines for wage movements.

Although there are numerous definitions of corporatism, one can argue that a high degree of corporatism is defined as a situation with highly centralized tripartite consultations. One can see corporatist elements in the labour relations of many countries. For example, in Dutch labour relations, corporatist elements have always played an important role. The famous Dutch guided wage policy (1950-1964) was an outstanding example of corporatist policy. Wages were determined at the central level and as a result wage increases were moderate during these years. However, the relevance of central bargaining has decreased since 1964. Wage negotiations have been shifting towards the industry level, which is by now the most important level in Dutch labour relations, although there are still consultations at the central level. The aim is to develop guidelines, starting points for the negotiations at the industry level. The results of the central consultations are not binding for the parties. Hence, if corporatism is defined as having consultations or negotiations at a highly centralized level, Dutch labour relations can be said to have corporatist elements. The same can be said for Austria, Germany and the Nordic countries (Delsen \& Van Veen, 1992).

We can summarize by saying that in our view two elements of corporatism need to be stressed. First, corporatism is characterized by tripartism. The government discusses major economic problems and how to solve them with employers and employees. Although tripartism occurs at various levels (industry, national), consultations at the central level are another major characteristic of corporatism.

\section{The theory of corporatism}

Why would it be advantageous for a country to have corporatist elements in its (labour) relations? In economics, Bruno \& Sachs (1985), in particular, have re-opened the discussion about the merits of corporatism. The main merit appears to be that economies with corporatist characteristics exhibit better economic performance. Wage increases are 
lower and adjustment processes are smoother. However, the emphasis in the literature is on the empirical results rather than on the theoretical framework. Often, Olson's theory of encompassing organizations is referred to (Olson, 1982). In this section we first give an overview of the various arguments that have been used in the literature to justify a relation between corporatism and economic performance. Second, we discuss some results of theoretical research concerning the relation between corporatism and economic performance.

What arguments have been used to provide a foundation for the positive impact of corporatism on economic performance?

- Large, national, encompassing organizations such as federations of employers and employees can to a large extent take account of the interests of all individuals, both employed and unemployed. This means that in central, tripartite, negotiations agreements can be concluded in such a way that unions and employers' organizations can co-determinate economic policy with regard to taxes, social security premiums and government expenditures. In exchange for this kind of co-determination, the labour market parties can promise to reduce wages.

- Negotiations at the central level prevent unions from competing for membership by promising higher wages.

- Encompassing organizations are better informed about the state of the economy. As a result nominal wages and prices will adjust more properly to shocks. Moreover, at the central level the parties will be aware of the danger that higher nominal wages may be followed by higher prices without changing the level of the real wages.

- Central agreements permit large-scale labour market policy with regard to schooling. They also make it easy to reach agreement about specific measures to increase employment.

- All kinds of procedures and legal rules with regard to the representation of employers and employees enhance feelings of consensus. It is often assumed that advice from encompassing organizations is easily accepted. This is reflected, for example, in a low level of strike activity and a low rate of inflation.

These arguments have been used to justify a positive relation between corporatism and economic performance. This means: the more centralized the wage negotiations are, the lower the wage rises and consequently inflation. Besides, corporatism would have a favourable effect on strike activity. Calmfors \& Driffill (1988), however, have been arguing that the relation is not monotonic positive, but parabolic. This implies that both fully centralized and fully decentralized decision-making would generate the same results with regard to economic performance. However, if wage bargaining is in between, i.e. mainly at the level of the industry, the economic performance is worse. 
To derive the relation between corporatism and economic performance, Calmfors \& Driffill (1988) use two arguments that work in opposite directions. First, encompassing organizations recognize that an increase in nominal wages may easily lead to an increase in the aggregate price level. Hence, a nationwide increase in nominal wages will not necessarily improve real wages. This moderates unions' wage demands. Therefore increases in nominal wages will be low or even absent with central bargaining. At the industry level however, the danger of a wage-price spiral is perceived differently because a wage increase in a specific industry has only a moderate effect on the aggregate price level. Consequently, nominal wage demands do make sense for one union at the industry level. However, if all industry unions act in the same way this results into a much larger price increase than each union expected. In the end no one is better off and only nominal wages and prices have increased. This argument can be called the real wage argument, which implies a positive relationship between the level of negotiation and the moderation of the wages.

Second, Calmfors \& Driffill (1988) argue that no one firm can increase its product price if it is faced with employees' wage demands, without incurring a severe loss in its competitive position (or in its profit) due to consumers switching to competitors. As a result employers will very strongly resist wage demands. This resistance diminishes when wage increases are industry-wide and even more when wage increases are nationwide. Moreover, the more centralized unions are, the higher their market power. Hence, this argument supports the idea that more centralized wage negotiations increase wages. This argument can be called the market power argument, which implies a negative relation between the level of wage negotiations and the extent of wage moderation.

It can be concluded from the analysis by Calmfors \& Driffill that there are arguments both for and against the idea that a high degree of centralization of wage bargaining helps to moderate the wage increases. They conclude that, instead of a monotonic relation, $a$ hump-shaped relation between corporatism ${ }^{1}$ and economic performance, especially as it is embodied in wages, may be the best approach. This means that real wages rise when wage bargaining shifts from the firm level to the industry level, but decrease when wage bargaining shifts further, to the central level.

Basically, the analysis fits into new-Keynesian analysis. If there is a coordination problem, it can be solved by a fully competitive system, by some kind of central organization or by

1. Note that corporatism is used as a synonym for centralization. In section 5 we return to this topic. 
an "in-between" system. ${ }^{2}$ However, if the problem is solved by an "in-between" system, the solution is not necessarily optimal ${ }^{3}$ (Mankiw \& Romer, 1991). From this point of view, and using game theory concepts, a lot of research has been carried out concerning whether central negotiations lead to a better result than decentralized negotiations (decentralized means here at the level of industry). The most important conclusion from this research is that coordination can lead to lower wage increases. Research by Mulder (1989), Jacobs \& Janssen (1990) and Abraham (1987) can illustrate this. Mulder (1989) has developed a model assuming a negative relation between wages and employment. If the government strives for a balanced budget, a wage increase and the resulting increase in unemployment will require an increase in the level of taxes. If wage negotiations are decentralized to the industry level, parties will treat the tax rate as a given beyond their influence. However, if wage negotiations are centralized, parties will realize the relation between a change in the wage rate and a change in the tax rate. Consequently, it is argued, centialized wage bargaining leads to a lower increase in wages. Jacobs \& Janssen (1990) have developed a two sector model with imperfect competition, where the wage in sector $A$ influences production in sector $B$. They show that where an increase in wages in sector $A$ creates negative effects in sectors $A$ and $B$, coordination is to be preferred above decentralization. The same conclusion is reached by Abraham (1987), although he assumes perfect competition on the goods market.

\section{Empirical research: an overview}

The relation between corporatism and economic performance (see also Cörvers \& Van Veen, 1992) is generally investigated by way of (multiple) regression analysis. About 18 OECD countries have been subjects for such research.

There are two major points of discussion concerning empirical research on the impact of corporatism on economic performance. First, there are various ways of measuring the phenomenon of corporatism. Second, there are several indicators of economic performance which can be regressed on corporatism.

How to measure corporatism?

Much of the empirical research on measuring corporatism has been inspired by Crouch

2. Perfect competition, a command economy and imperfect competition can be seen as ways to coordinate the decisions of economic agents.

3. In the sense that a different way of organizing could improve the results. 
(1985): e.g. Bruno \& Sachs (1985), McCallum (1986) and Freeman (1988). Crouch (1985) classifies 18 OECD countries into neocorporatist and liberal countries. (Neo)corporatism in the Crouch's sense refers to the degree of coordination at the bargaining table, i.e. the extent to which labour unions and employer organizations are coordinated. ${ }^{4}$

Crouch shows that labour conflicts are less and the sum of inflation and unemployment is lower when union membership is high. He uses a simple statistical technique: diagrams.

In a regression analysis, a dummy or an index is used to indicate the strength of the corporatist elements in a country. Crouch's classification is used by Freeman (1988) for the construction of his dummy variable. However, most researchers prefer the use of an index of corporatism to construct a rank ordering of industrialized countries. The indices of Bruno \& Sachs $(1985)$ and McCallum $(1983,1986)$ increase with the centralization of employers' associations and labour unions, with the decline of shop-floor union power, and when works councils are present. The index of Cameron (1984) measures corporatism by highlighting only the organizational power of employees, i.e. the membership rates and the degree of centralization of unions. Schmidt's index (1982) takes account of a number of variables, including the consensus between the government and employers' and employees' representatives, and the strike activity of employees. It follows that many different variables are used to measure corporatism, which partly reflects the discussion about the concept of corporatism. We will return to this topic in section 5 .

\section{What is economic performance?}

Several indicators of economic performance can be regressed on corporatism. Table 1 shows the results of empirical research concerning the relationship between corporatism and economic performance, measured by real wages, unemployment, inflation and strike activity. A coefficient of regression indicates that there are other independent variables included in the regression analysis. If there is a coefficient of correlation, the corporatism variable is taken as the only independent variable. The overall picture in Table 4.1 supports the presumption that the presence of corporatist elements has a favourable effect on wage control, unemployment, inflation, and strike activity. All presented coefficients show the expected sign and most of them are significant. The dummy variable for unemployment in Freeman's research is close to significance. Wilke (1991) also evaluates the results of empirical research into the relationship between corporatism and employment. He concludes that corporatist elements in a country help to decrease the unemployment rate.

4. Crouch's definition of corporatism will be discussed more extensively in the next section. 
Table 4.1

Results of empirical research on the relationship between corporatism and economic performance.

researchers period $\quad \begin{aligned} & \text { measure of } \\ & \text { corporatism }\end{aligned} \quad$ result

\begin{tabular}{|c|c|c|c|}
\hline \multicolumn{4}{|c|}{ Corporatism $(K)$ and real wages $(w)$} \\
\hline Bruno \& Sachs (1985) & $1973-79$ & index & $\begin{array}{l}b(w, K)=-1.11^{*} \\
r(w, K)=-0.64^{*}\end{array}$ \\
\hline Freeman (1988) & $1979-85$ & dummy & $\mathrm{b}(\mathrm{w}, \mathrm{K})=-4.28^{*}$ \\
\hline Cameron (1984) & $1965-82$ & index & $r(w, K)=-0.52^{*}$ \\
\hline \multicolumn{4}{|c|}{ Corporatism and unemployment (U), employment (E) } \\
\hline Schmidt (1982) & $1960-73$ & index & $r(U, K)=-0.53^{*}$ \\
\hline Schmidt (1982) & $1974-78$ & index & $r(U, K)=-0.67^{*}$ \\
\hline Cameron (1984) & $1965-82$ & index & $r(U, K)=-0.40^{*}$ \\
\hline Freeman (1988) & 1984 & dummy & $b(U, K)=-5.41$ \\
\hline Freeman (1988) & $1979-84$ & dummy & $b(E, K)=5.99^{*}$ \\
\hline \multicolumn{4}{|c|}{ Corporatism and inflation $(P)$} \\
\hline Bruno \& Sachs (1985) & $1973-79$ & index & $b(P, K)=-1.54^{*}$ \\
\hline McCallum (1983) & $1968-73$ & index & $r(P, K)=-0.1$ \\
\hline McCallum (1983) & $1971-79$ & index & $b(P, K)=-0.86^{*}$ \\
\hline Cameron (1984) & $1965-80$ & index & $r(P, K)=-0.18$ \\
\hline \multicolumn{4}{|c|}{ Corporatism and strike activity (S) } \\
\hline Bruno \& Sachs (1985) & $1965-80$ & index & $r(S, K)=-0.50^{*}$ \\
\hline McCallum (1983) & $1950-69$ & index & $r(S, K)=-0.76^{*}$ \\
\hline McCallum (1986) & $1950-78$ & index & $r(S, K)=-0.68^{*}$ \\
\hline Cameron (1984) & $1965-82$ & index & $r(S, K)=-0.47^{*}$ \\
\hline
\end{tabular}

Notes: $\quad b(y, x)$ is the regression coefficient of $y$ on $x$, whereas $r(y, x)$ represents the correlation coefficient between $y$ and $x$. An asterisk indicates a significant coefficient at a $5 \%$ level.

\section{Comments}

There are some important shortcomings in this empirical research. First, the frameworks used in the studies differ from each other. The independent corporatism variable is part of an economic-theoretical framework, with each study using independent variables that differ from the variables in other studies. Second, the empirical research listed here extends over a long time. In most of the research the strength of corporatist elements is assumed to be stable (the index is kept fixed), although labour relations are constantly developing in some direction. The centralization/decentralization debate regarding wage bargaining has been going on for a long time in corporatist countries such as the Netherlands and the Scandinavian countries (Delsen \& Van Veen, 1992). This has an influence on the labour relations. Third, there are many institutional and economic differences between the OECD countries. It is not clear to what extent corporatist elements account for the diverging 
economic performances of countries which are subject to various macroeconomic policies. Fourth, although corporatism is a multi-dimensional variable, it is generally being measured only along one dimension, e.g. the centralization of wage bargaining. In section 3 , however, we have stressed that co-determination in economic policy is also an important idea behind corporatism. Hence, one might expect that government policy would differ between corporatist and non-corporatist countries. In the next section we will elaborate on this point.

\section{Can corporatism be measured on a one-dimensional scale?}

In the previous section we gave an overview of empirical research concerning the relation between corporatism and economic performance. The work of Crouch (1985) has been mentioned as an important source for this research. In Crouch's work, the coordination of wage bargaining is an important indicator of corporatism. The centralization index of Calmfors \& Driffill (1988) has also been rather popular in recent literature.

Both Crouch and Calmfors \& Driffill argue that the degree of centralization of wage bargaining is a crucial factor for macroeconomic performance. However, Crouch (1985) also emphasizes the importance of the representation of the labour movement by political parties. Moreover, not only formal structures regarding centralization matter, but also informally centralized groups of workers and social peace agreements in industrial relations. In contrast, for Calmfors \& Driffill (1988) the formal degree of centralization of the bargaining process is all that matters. Their centralization index is constructed by using two indicators. First, the levels of coordination within national union confederations and within national employer organizations, i.e. at the national, the industry or the enterprise level. Second, the number of central union confederations and the extent of their cooperation, and the number of central employer organizations and the extent of their cooperation. However, both Crouch and Calmfors \& Driffill have based their classification to a large extent on one dimension, viz. the level at which the bargaining between employees and employers takes place.

But corporatism may in fact be a multidimensional variable. Section 2 suggests that corporatism is not only characterized by centralization or coordination of labour relations, but also by an active government socio-economic policy in tripartite negotiations with employers' organizations and labour unions. One essential element in a definition of corporatism may be the degree of coordination by the government versus coordination by the market. The involvement of the government is suggested by both sociological and economic research. From a sociological point of view, the concept of corporatism is much 
broader than labour relations alone. This is illustrated for example by Schmitter (1981), Lehmbruch (1984), and by the research of Crouch (1985) which was mentioned above. Schmidt (1982), in particular, stresses the role of the government in corporatist societies. The more the government is involved in the economy, the higher the degree of corporatism. This implies e.g. higher tax rates and tax revenues, a larger system of collective insurances against unemployment, health problems etc. Moreover, the provision of public goods will be at a higher level. However, not only the relative magnitude, but also the composition of government expenditures can be different between countries. Corporatist countries are assumed to pay more attention to matters such as schooling, subsidized employment etc. to fight unemployment. From an economic point of view, the importance of the government in socio-economic policy is illustrated in various papers in a special edition of the Scandinavian Journal of Economics (1985).

\section{Hypotheses}

We have argued that, apart from coordination/centralization in the wage negotiations, the role of the government differs between corporatist and non-corporatist countries. We have developed seven hypotheses that allow us to test whether there is a difference in this respect between corporatist and non-corporatist countries. The hypotheses cover government expenditures, taxes, union membership and labour force participation. Basically we test whether differences on these points between corporatist countries and non-corporatist countries are significant. Note that we use the definitions of Crouch and Calmfors \& Driffill to determine which countries are corporatist. We will first present the hypotheses, and then in section 6 , the method and results of our empirical research.

If we conclude that corporatist countries differ from non-corporatist countries in terms of our criteria, then centralization of wage bargaining can be seen as a representative characteristic of corporatism. Note however, that this implies that corporatist countries are not only characterized by the level of wage bargaining. Economic or government policy is also an indicator of corporatism. If, on the other hand, the determination of which countries are corporatist differs using the bargaining level criteria and our criteria, which focus on the role of the public sector, then it really does matter how corporatism is defined. In that case the degree if centralization of wage bargaining would not necessarily be a good proxy for corporatism.

We have formulated the hypotheses $H_{0}$ in table 4.2 Hypotheses $1-4$ follow from our discussion in section 2 and 3 . In these sections we have stressed tripartism as a characteristic of a corporatist society. Moreover we also consider the structure of the expenditures, as far as they relate to labour market policy e.g. expenditures on vocational 
training, youth measures, subsidised employment, measures for the disabled, unemployment compensation and early retirement. Tripartism, of course, yields better results the more the various organizations are seen as representative bodies. For example, centralized wage negotiations only make sense if unions substantially represent the labour force (hence hypothesis 5 ). ${ }^{5}$ Sometimes it is argued that in corporatist countries, (female) participation in the labour market is heavily stimulated. Both emancipation and financial need feature in the argumentation (Van Paridon, 1990). Hence we have formulated two hypotheses about the participation rate, hypotheses 6 and 7 .

\section{Table 5.1}

Hypotheses

1. The government expenditures/GNP ratio is higher in corporatist than in non-corporatist countries.

2. The taxes and contributions for social security/GNP ratio is higher in corporatist than in noncorporatist countries.

3. The average and marginal tax rates are higher in corporatist than in non-corporatist countries.

4. Public expenditure on labour market programmes is larger in corporatist than in noncorporatist countries.

5. Union membership rates are higher in corporatist than in non-corporatist countries.

6. Labour force participation is larger in corporatist than in non-corporatist countries.

7. Female labour force participation is larger in corporatist than in non-corporatist countries.

\section{Results}

\section{Linear classification}

Since we are interested in knowing whether corporatist countries differ from non-corporatist countries with regard to the hypotheses as formulated above, we have used an independent-samples test. ${ }^{6}$ This technique allows us to test whether the average scores of corporatist countries differ from those of non-corporatist countries (using both Crouch's and Calmfors \& Driffill's classifications). We have decided to consider the period from 1970.

5. Note that we consider only employees. Dutch and Scandinavian history shows that labour market organization has started with employees. Employers'organizations seem to be a response.

6. To be more exact: we used the Independent Samples Test for a comparison of the means and variances of the samples of corporatist and non-corporatist countries. Both pooled and separate-variance estimates are calculated, in order to test (at a $10 \%$ significance level) the homogeneity of variances of the samples of corporatist and non-corporatist countries. 
We first present the corporatism classifications based on Crouch and Calmfors \& Driffill. The background of these classifications has been discussed in section 5 . Crouch (1985) subdivides eighteen developed countries into a group of corporatist and a group of liberal (i.e. non-corporatist) countries (see Table 6.1).

Table 6.1

Crouch's classification

corporatist non-corporatist

$\begin{array}{ll}\text { Austria } & \text { Australia } \\ \text { Denmark } & \text { Belgium } \\ \text { Finland } & \text { Canada } \\ \text { Germany } & \text { France } \\ \text { The Netherlands } & \text { Ireland } \\ \text { Norway } & \text { Italy } \\ \text { Sweden } & \text { Japan } \\ \text { Switzerland } & \text { New Zealand } \\ & \text { United Kingdom } \\ & \text { United States }\end{array}$

Based on the centralization of negotiations, Calmfors \& Driffill (1988) establish a ranking from one to seventeen in descending order of corporatism. We have transformed this ranking into a classification of corporatism by designating the first seven countries in their list to the corporatist group of countries and the remaining countries to the non-corporatist group. ${ }^{7}$ The result is called the Calmfors \& Driffill's linear classification (see table 6.2).

We now have two classifications which only differ with respect to one country. Switzerland is included in the corporatist group by Crouch and in the non-corporatist group by Calmfors \& Driffill. The reason for this difference is in the differing definitions of corporatism that we have discussed in section 5 . The level of negotiations plays a more important role in Calmfors \& Driffill than in Crouch. Calmfors \& Driffill give Switzerland a low ranking, because in Switzerland the bargaining takes place at a decentralized (i.e. firm) level. Crouch terms Switzerland a corporatist country, because the industrial relations are heavily coordinated by social peace agreements and informally by centralized groups (e.g. of union representatives).

7. Ireland has been added to the latter group. Most studies agree on the non-corporatist nature of Ireland. See e.g. Cameron (1984), Crouch (1985) and Schmitter (1981). 
Table 6.2

Calmfors \& Driffill's linear classification

corporatist non-corporatist

\begin{tabular}{ll} 
Austria & Australia \\
Denmark & Belgium \\
Finland & Canada \\
Germany & France \\
The Netherlands & Ireland \\
Norway & Italy \\
Sweden & Japan \\
& New Zealand \\
& United Kingdom \\
& United States \\
& Switzerland \\
\hline
\end{tabular}

A lucky consequence of the minor difference between the two corporatism classifications, is the possibility it creates to analyze the sensitivity of the empirical testing by including Switzerland in either the corporatist or the non-corporatist group of countries.

We first tested whether government expenditures and income tax rates, union density, labour market policy measures and participation rates differ between corporatist and noncorporatist countries as they have been classified by Crouch and Calmfors \& Driffill. We have taken several measurements during the period 1970-1990, where data was available.

The results of this test are summarized in table 6.3 (Crouch's classification) and table 6.4 (Calmfors \& Driffill's classification). The complete results are given in the appendix. The first column in each of the tables shows the variable that is subject to testing. The name of the variable is followed by the year of measurement. For example, EXP85 means that this result concerns 1985 . The second column gives the mean value of that variable for corporatist countries and in the third column this value is shown for the non-corporatist countries. More details as to the way the data is composed are provided in the data appendix. The final column provides the P-value of the test. ${ }^{8}$

First we note that corporatist countries have, on average, higher expenditures and tax revenues (related to GDP) and higher tax rates. Union density is also higher, as are the participation rates. Moreover, labour market policy seems to differ, in favour of more active policy measures in corporatist countries. Finally, average unemployment benefits are

8. Note that the $(1-P)$-value is the probability that $H_{0}$ is valid. 
higher in corporatist countries (see Table 6.3 and appendix).

Table 6.3

Results for Crouch's (linear) classification

\begin{tabular}{llll}
\hline Variable & Mean-corp & Mean-non & P-value \\
\hline
\end{tabular}

$\begin{array}{lccc}\text { Hypothesis 1: Government Expenditures } & & \\ \text { EXP85 } & 37.8 & 37.6 & 0.9702 \\ \text { EXP90 } & 37.6 & 35.0 & 0.6214 \\ \text { Hypotheses 2 and 3: Taxes } & 42.8 & 35.6 & 0.0311 \\ \text { TAX85 } & 43.2 & 36.9 & 0.0532 \\ \text { TAX90 } & 36.7 & 30.2 & 0.2237 \\ \text { ATTR91 } & 49.0 & 42.9 & 0.3256 \\ \text { MTTR91 } & 0.87 & & \\ \text { Hypotheses 4: Labour Market Programmes } & 0.70 & 0.5310 \\ \text { TAM85 } & 0.95 & 0.68 & 0.2209 \\ \text { TAM90 } & 1.23 & 1.75 & 0.3524 \\ \text { PAS85 } & 1.51 & 1.49 & 0.9673 \\ \text { PAS90 } & 0.91 & 0.47 & 0.1854 \\ \text { TAM/PAS85 } & 0.90 & 0.50 & 0.1001 \\ \text { TAM/PAS90 } & & \\ \text { Hypotheses 5: Union Density } & 43.5 & 0.2330 \\ \text { UNDE80 } & 55.0 & 39.7 & 0.1843 \\ \text { UNDE85 } & 53.8 & & \\ \text { Hypotheses } 6 \text { and 7: Participation Rates } & 62.3 & 0.0992 \\ \text { PART87 } & 69.8 & 70.0 & 0.1085 \\ \text { PART90 } & 75.5 & 50.9 & 0.1453 \\ \text { FPART87 } & 59.9 & 58.0 & 0.1188 \\ \text { FPART90 } & 66.1 & & \end{array}$

Notes:

EXP is government expenditures; TAX is total taxes related to GNP; ATTR is the average total tax rate. MTTR is the marginal total tax rate. TAM and PAS concern labour market policy: TAM stands for total of active measures; PAS stands for total of passive measures. UNDE is union density employed. PART and FPART are net participation and female net participation, respectively. More detailed information about the data is provided in the data appendix.

The significance of the results is, however, not always convincing. The ratio of government expenditures to GDP does not differ significantly between the two types of countries, although the significance increases when Switzerland is labelled as a non-corporatist country. Tax revenues seem to differ significantly between corporatist and non-corporatist countries. However, average and marginal tax rates only differ significantly when Switzerland is defined as non-corporatist. Obviously, Switzerland is characterized by low average and marginal tax rates. The same is true for the union density variable: if Switzerland is called non-corporatist, the significance of the difference in union density between corporatist and non-corporatist countries improves from $20 \%$ to $10 \%$. The 
difference in participation rates shows a significant difference at a $10 \%$ level, although this does not hold for the variable that measures female participation. Again, however, this result is sensitive to how Switzerland is included. The significance of the difference in average unemployment benefits is independent of how Switzerland is treated (see appendix).

Table 6.4

Results for Calmfors \& Driffill's linear classification

\begin{tabular}{|c|c|c|c|}
\hline Variable & Mean-corp & Mean-non-corp & P-value \\
\hline \multicolumn{4}{|c|}{ Hypotheses 1: Government Expenditures } \\
\hline EXP85 & 40.2 & 36.1 & 0.4794 \\
\hline EXP90 & 39.9 & 33.7 & 0.2513 \\
\hline \multicolumn{4}{|c|}{ Hypotheses 2 and 3: Taxes } \\
\hline TAX85 & 44.3 & 35.3 & 0.0051 \\
\hline TAX90 & 44.9 & 36.4 & 0.0165 \\
\hline ATTR91 & 58.5 & 29.6 & 0.0901 \\
\hline MTTR91 & 51.4 & 41.8 & 0.1210 \\
\hline \multicolumn{4}{|c|}{ Hypotheses 4: Labour Market Programmes } \\
\hline TAM85 & 0.98 & 0.65 & 0.2285 \\
\hline TAM90 & 1.05 & 0.63 & 0.0556 \\
\hline PAS85 & 1.39 & 1.61 & 0.6961 \\
\hline PAS90 & 1.70 & 1.36 & 0.5231 \\
\hline TAM/PAS85 & 0.94 & 0.49 & 0.1164 \\
\hline TAM/PAS90 & 0.80 & 0.59 & 0.3634 \\
\hline \multicolumn{4}{|c|}{ Hypotheses 5: Union Density } \\
\hline UNDE80 & 58.5 & 41.9 & 0.0754 \\
\hline UNDE85 & 57.3 & 38.4 & 0.0630 \\
\hline \multicolumn{4}{|c|}{ Hypotheses 6 and 7: Participation Rates } \\
\hline PART87 & 69.4 & 63.5 & 0.1833 \\
\hline PART90 & 75.1 & 70.8 & 0.2297 \\
\hline FPART87 & 60.7 & 51.2 & 0.1291 \\
\hline FPART90 & 67.0 & 58.1 & 0.1162 \\
\hline
\end{tabular}

Notes: see table 6.3

Labour market policy seems to be a difficult variable. Neither total active labour market measures nor total passive measures show a significant difference. Apart from the measures for the disabled, the same is true when we split these measures into their various components (see appendix). The significance increases, however, when the ratio of active to passive measures is taken into account.

Apart from the reported results, we have also tested for difference in some other variables. For example, not only might taxes differ between corporatist and non-corporatist countries, but also social security contributions. However, social security contributions as a 
percentage of GDP do not show significant differences: the averages of both corporatist and non-corporatist countries lie around $10 \%$, and do not differ more than 1 percentage point (in either 1985 or 1990).

\section{Parabolic classification}

One of the main contributions of Calmfors \& Driffill has been the idea that not a linear relation, but a parabolic or hump-shaped relationship best describes the relation between corporatism and economic performance. We can use this idea to test whether there is also a parabolic relationship with regard to taxes etc. In other words, we can test whether strongly non-corporatist and strongly corporatist countries show the same characteristics. Since the idea behind Calmfors \& Driffill's model is that both extremes on the corporatist scale lead to the same economic performance, one might ask whether this is due to characteristics like taxes, labour market policy and participation rates. According to the hypotheses that we have defined, one can argue that if a parabolic relation exists, countries on both extremes will show about the same value for the characteristic in question. But one might expect an inverse hump shape (a $U$ form): outlays for active labour market policies and labour force participation rates would be higher in extreme corporatist and extreme non-corporatist countries in order to be able to explain the Calmfors \& Driffill hump shape. Moreover, this value must differ from the value of the countries that are "stuck in the middle". However, since a linear and parabolic relationship cannot exist at the same time, we can only execute this test if the previous test has showed an insignificant result in the difference in average value in the variable concerned.

Table 6.5

Calmfors \& Driffill's parabolic classification

extreme middle

$\begin{array}{ll}\text { Austria } & \text { Australia } \\ \text { Canada } & \text { Belgium } \\ \text { Denmark } & \text { France } \\ \text { Finland } & \text { Ireland } \\ \text { Germany } & \text { Italy } \\ \text { Norway } & \text { Japan } \\ \text { Sweden } & \text { The Netherlands } \\ \text { Switzerland } & \text { New Zealand } \\ \text { United States } & \text { United Kingdom }\end{array}$

For this test we subdivided the 18 countries into a mixed group of extreme corporatist and extreme non-corporatist countries, and a group of countries that is 'stuck in the middle' 
(according to Calmfors \& Driffill). This result is called the Calmfors \& Driffill's parabolic classification and is presented in table 6.5.

The results of this test are given in table 6.6 Government expenditures are significantly higher in countries that are "stuck in the middle". Further, we note that the ratio of active to passive labour market policy is higher in the countries that are labelled "extreme", due to the lower outlays for passive labour market policies. With regard to the levels of significance, we note that, with a few exceptions, labour market policies show no significant difference. Hence, we conclude that neither a significant linear, nor a significant parabolic relation exists. However, as before, participation rates show a significant difference: they are higher in the countries that are labelled "extreme".

From these results we can conclude that with regard to government expenditures and participation rates, "extreme" countries indeed differ from "middle" countries.

\section{Evaluation}

The results include some interesting features. First, the share of the public sector in the total economy, indicated by the EXP and TAX variables, is closely related to both the linear Crouch and the linear Calmfors \& Driffill index. For the TAX variable, all P-values (except one) show significance levels of $5 \%$ or less. As Switzerland is the only country which is allocated to different groups in the two indices, we may conclude that the relationship between corporatism and the volume of the public sector is relatively stable. However, the average and marginal tax rates (ATTR91 and MTTR91, respectively) do not differ so significantly. Only the average tax rate is significant at a $10 \%$ level in the case of the Calmfors \& Driffill linear classification.

Second, the union density variable only performs well with the linear Calmfors \& Driffill classification. However, this means that the relationship between corporatism and union density is very sensitive to whether Switzerland is assigned to the corporatist or to the noncorporatist group of countries. For this reason the linear hypothesis regarding corporatism and union density cannot be accepted.

Third, our hypotheses with regard to the labour market policies could not be accepted. Expenditures on active labour market policies do not differ significantly. One reason for this result may be that many active labour market policies can be seen as supply side policies, e.g. labour market training programmes, youth measures. However, as has also been shown in Delsen \& Van Veen (1992), the ratio of active to passive labour market policies certainly differs in favour of a higher ratio in corporatist countries. 
Table 6.6

Results for Calmfors \& Driffill's parabolic classification

\begin{tabular}{llll}
\hline Variable & Mean-mid & Mean-ext & P-value \\
\hline \multicolumn{2}{l}{ Government Expenditures } & & \\
EXP85 & 42.5 & 32.8 & \\
EXP90 & 39.5 & 32.7 & 0.0744 \\
Labour Market Policies & & & 0.1914 \\
TAM85 & 0.80 & 0.74 & 0.8107 \\
TAM90 & 0.79 & 0.81 & 0.9131 \\
PAS85 & 2.03 & 0.98 & 0.0407 \\
PAS90 & 1.63 & 1.36 & 0.6105 \\
TAM/PAS85 & 0.47 & 0.85 & 0.1867 \\
TAM/PAS90 & 0.52 & 0.83 & 0.1657 \\
Participation Rates & & & 0.0030 \\
PART80 & 62.5 & 71.2 & 0.0026 \\
PART87 & 60.0 & 71.6 & 0.0014 \\
FPART80 & 43.7 & 58.9 & 0.0062 \\
FPART87 & 47.2 & 62.6 & \\
\end{tabular}

Fourth, our data shows higher participation rates in corporatist countries. This is in accordance with our hypotheses. The relation is not completely clear, however. The Crouch division gives the best results. But because of the high participation rates in Switzerland, the results deteriorate when we use the Calmfors \& Driffill division. But if we then test for an inverse hump shape the results are significant too.

\section{Conclusions}

The theoretical part of the paper suggests that corporatism has two important characteristics, viz. tripartism and consultations at the central level. Moreover, the empirical review reveals that corporatism seems to have advantageous effects on (un)employment, real wages, inflation and strike activity.

Our own empirical analysis leads to some interesting conclusions. First of all, corporatist countries are not only characterized by centralization or coordination of wage bargaining, but also by relatively high government expenditures (although not significantly higher) and tax revenues (significantly higher). Further we note that corporatist countries do show a higher ratio of active to passive labour market policies and also show higher average unemployment benefits. 
However, the results show that the correlations between corporatism as measured by the centralization of wage bargaining on the one hand and, on the other hand, the variables following from the hypotheses, depend relatively strongly on which type of classification of countries is used. Firstly, the results with regard to average and marginal total tax rates, union density and participation rates are sensitive to whether Switzerland is assigned to the corporatist group or the non-corporatist group. Secondly, the analysis of the participation rates suggests an inverse hump-shape relation, with high rates in both extreme corporatist and extreme non-corporatist countries. This also holds, to a much lesser extent, for government expenditures.

Finally, the aim of the research was to discover whether centralized wage bargaining is a good characteristic of corporatism. Our results show that a division of countries into corporatist and non-corporatist groups using the centralization criterion also holds for other criteria, in particular tax revenues, and to a lesser extent also government expenditures, union density and participation rates. Whether this implies that government expenditures and taxes (relative to GDP), rather than the centralization of labour relations, are the basic causes of the differences between the economic performances of the countries is a topic for further research.

\section{References}

Abraham, F. (1987), Bargaining Structures and Macroeconomic Performance in a Small Open European Economy with Imperfectly Competitive World Markets, Discussion Paper 200, University of Michigan.

Abraham, F. (1989), Unions and Government, What does Economic Theory (Not) Tell Us? Okonomie und Gesellschaft, Jahrbuch 7, Campus Verlag, pp. 95-115.

Bruno, M. and J. Sachs (1985), The Economics of Worldwide Stagflation, Harvard University Press, Cambridge, Mass.

Calmfors, L. and J. Driffill (1988), Centralization of Wage Bargaining, Economic Policy, 3(1), pp. 1361.

Cameron, D.R. (1984), Social Democracy, Corporatism, Labour Quiescence and the Representation of Economic Interest in Advanced Capitalist Societies; in J.H. Goldthorpe (ed.), Order and Conflict in Contemporary Capitalism, Oxford University Press, Oxford.

Cörvers, F. and A.P. van Veen (1992), Corporatisme en Economische Ontwikkeling, Economisch Statistische Berichten, 9-12-1992, pp. 1189-1193.

Delsen, L. and T. van Veen (1992), The Swedish Model, Relevant for Other European Countries?, British Journal of Industrial Relations, 30(1), March, pp. 83-106.

Freeman, R. (1988), Labour Market Institutions and Economic Performance, Economic Policy, 6, pp. 64-80.

Jacobs, J. and M. Janssen (1990), Coordinating Unions Wages and Employment, De Economist, 138(3), pp. 321-339. 
Lehmbruch, G. (1984), Concertation and the Structure of Corporatist Networks; in J.H. Goldthorpe (ed.), Order and Conflict in Contemporary Capitalism, Oxford University Press, Oxford.

Mankiw, N.G. and D. Romer (1991), New-Keynesian Economics, vol. 1\&2, MIT Press, Cambridge.

McCallum, J. (1983), Inflation and Consensus in the Seventies, Economic Journal, pp. 784-805.

McCallum, J. (1983), Unemployment in the OECD Countries, Economic Journal, pp. 944-963.

Moene, K.O, M. Wallerstein and M. Hoel (1992), Bargaining Structure and Economic Performance, Memorandum 10, Faculty of Economics, University of Oslo.

Mulder, C. (1989), New Classical Macroeconomics, Trade Unions and Unemployment, PhD thesis, London School of Economics.

OECD, Employment Outlook, 1992: Table 2.15 and annex 2.B

Olson, M. (1982), The Rise and Decline of Nations, Yale University Press, New Heaven, Connecticut.

Paridon, C.W.A.M. van (1990), Arbeidsmarktparticipatie in Nederland, Plaatsbepaling in International Perspectief, Wetenschappelijke Raad voor het Regeringsbeleid, Den Haag.

Schmidt, M.G. (1982), Does Corporatism Matter? in G. Lehmbruch and P. Schmitter, Patterns of Corporatist Policy-making, Sage.

Schmitter, P.C. (1981), Interest Intermediation and Regime Governablility in Contemporary Western Europe and North America; in S.D. Berger (ed.), Organizing Interests in Western Europe, Cambridge University Press, Cambridge, Mass.

The Scandinavian Journal of Economics (1985), Proceedings of a Conference on Trade Unions, Wage Formation and Macroeconomic Stability, 87(2).

Wilke, M. (1991), Corporatism and the Stability of Capitalist Democracies, Peter Lang. 



\section{Data appendix}

$\operatorname{EXP}(X)$ : Total Central Government expenditures as a percentage of gross domestic product in year $X$ (Government Finance Statistics Yearbook, 1992, IMF).

TAX(X) : Total Tax Revenues as a Percentage of Gross Domestic Product in year $X$ (Revenue Statistics of OECD Member Countries, OECD, 1991).

$\operatorname{ATTR}(X)$ : $\quad$ Average Total Tax Rate, percent of average earnings plus employers' social security, in year X (Economic Survey, OECD, 1993).

$\operatorname{MTTR}(X)$ : $\quad$ Marginal Total Tax Rate, percent of average earnings plus employers' social security, in year X (Economic Survey, OECD, 1993).

$\operatorname{TAM}(X)$ : Total of Active Measures in year $X$, includes (1) Public Employment Services and Administration, (2) Labour Market Training, (3) Youth Measures, (4) Subsidised Employment, and (5) Measures for the disabled (Employment Outlook, OECD, July 1992).

$\mathrm{PAS}(\mathrm{X}) \quad$ : $\quad$ Total passive measures in year $\mathrm{X}$, includes Unemployment Compensation and Early Retirement for Labour Market Reasons (Employment Outlook, OECD, July 1992).

LMT(X) : Labour Market Training in year $X$, includes (1) training for unemployed adults and those at risk and (2) training for employed adults (Employment Outlook, OECD, July 1992).

$\mathrm{YM}(\mathrm{X}) \quad$ : $\quad$ Youth Measures in year $X$, includes (1) measures for unemployed and disadvantaged youth and (2) support of apprenticeship and related forms of general youth training (Employment Outlook, OECD, July 1992).

$\mathrm{SE}(X) \quad$ : $\quad$ Subsidised unemployment in year $X$, includes (1) Subsidies to regular employment in the private sector, (2) Support of unemployed persons starting enterprises and (3) direct job creation (public or non-profit) (Employment Outlook, OECD, July 1992).

$\operatorname{MD}(X) \quad$ : $\quad$ Measures for the Disabled in year $X$, includes (1) vocational rehabilitation and (2) work for the disabled (Employment Outlook, OECD, July 1992).

$\mathrm{UC}(\mathrm{X})$ : Unemployment Compensation in Year $\mathrm{X}$ (Employment Outlook, OECD, July 1992).

$\mathrm{AUB}(\mathrm{X}) \quad$ : $\quad$ Average Unemployment Benefits, as percentage of average earnings plus employers' social security, in year X (Economic Survey, OECD, 1993).

The average unemployment benefit has been calculated as theoretical expenditure on the unemployed divided by the total number of unemployed. This average benefit figure may be lower than theoretical entitlements to benefits due to eligibility restrictions.

$\operatorname{UNDR}(X)$ : $\quad$ Union Density Recorded in year X (Employment Outlook, OECD, 1991) 
$\operatorname{UNDE}(X)$ : $\quad$ Union Density Employed in year X (Employment Outlook, OECD, 1991).

$\operatorname{PART}(\mathrm{X})$ : $\quad$ Net labour Market participation rate in year $X$, total, (employment in labour years/relevant labour force) (Arbeidsmarktparticipatie in Nederland; plaatsbepaling in internationaal perspectief, WRR, 1990).

$\operatorname{FPART}(X)$ : $\quad$ Net labour market participation in year $X$, female (Arbeidsmarktparticipatie in Nederland; plaatsbepaling in internationaal perspectief, WRR, 1990). 
Table $6.3^{a}$

Results for Crouch's (linear) classification

\begin{tabular}{|c|c|c|c|}
\hline Variable & Mean-corp & Mean-non & P-value \\
\hline \multicolumn{4}{|c|}{ Government Expenditures } \\
\hline EXP80 & 36.1 & 34.2 & 0.7046 \\
\hline EXP85 & 37.8 & 37.6 & 0.9702 \\
\hline EXP90 & 39.9 & 35.0 & 0.3570 \\
\hline \multicolumn{4}{|l|}{ Taxes } \\
\hline TAX70 & 35.2 & 29.6 & 0.0517 \\
\hline TAX75 & 39.1 & 31.3 & 0.0093 \\
\hline TAX80 & 41.4 & 33.3 & 0.0149 \\
\hline TAX85 & 42.8 & 35.6 & 0.0311 \\
\hline TAX90 & 43.2 & 36.9 & 0.0532 \\
\hline ATTR91 & 36.7 & 30.2 & 0.2237 \\
\hline MTTR91 & 49.0 & 42.9 & 0.3256 \\
\hline \multicolumn{4}{|c|}{ Labour Market Programmes } \\
\hline TAM85 & 0.87 & 0.70 & 0.5310 \\
\hline TAM90 & 0.95 & 0.68 & 0.2209 \\
\hline PAS85 & 1.23 & 1.75 & 0.3524 \\
\hline PAS90 & 1.51 & 1.49 & 0.9673 \\
\hline TAM/PAS85 & 0.91 & 0.47 & 0.1854 \\
\hline TAM/PAS90 & 0.90 & 0.50 & 0.1001 \\
\hline LMT85 & 0.20 & 0.19 & 0.9894 \\
\hline LMT90 & 0.30 & 0.23 & 0.4206 \\
\hline YM85 & 0.07 & 0.18 & 0.1672 \\
\hline YM90 & 0.09 & 0.14 & 0.4751 \\
\hline SE85 & 0.22 & 0.26 & 0.7475 \\
\hline SE90 & 0.15 & 0.14 & 0.9103 \\
\hline MD85 & 0.29 & 0.05 & 0.0825 \\
\hline MD90 & 0.31 & 0.07 & 0.0315 \\
\hline UC85 & 1.13 & 1.63 & 0.3444 \\
\hline UC90 & 1.27 & 1.42 & 0.7282 \\
\hline AUB91 & 44.2 & 24.8 & 0.0073 \\
\hline \multicolumn{4}{|c|}{ Union Density } \\
\hline UNDR75 & 60.4 & 49.0 & 0.1847 \\
\hline UNDR80 & 64.3 & 50.4 & 0.2000 \\
\hline UNDR85 & 63.6 & 53.5 & 0.3905 \\
\hline UNDE75 & 53.3 & 43.2 & 0.2246 \\
\hline UNDE80 & 55.0 & 43.5 & 0.2330 \\
\hline UNDE85 & 53.8 & 39.7 & 0.1843 \\
\hline
\end{tabular}




\section{Participation Rates}

$\begin{array}{llll}\text { PART70 } & 69.1 & 64.7 & 0.0952 \\ \text { PART80 } & 70.2 & 64.2 & 0.0628 \\ \text { PART87 } & 69.8 & 62.3 & 0.0992 \\ \text { PART90 } & 75.5 & 70.0 & 0.1085 \\ \text { FPART70 } & 49.0 & 42.3 & 0.1501 \\ \text { FPART80 } & 56.9 & 46.8 & 0.0559 \\ \text { FPART87 } & 59.9 & 50.9 & 0.1453 \\ \text { FPART90 } & 66.1 & 58.0 & 0.1188\end{array}$

Notes:

- The samples of corporatist and non-corporatist countries are not always complete, depending on the availability of the data. For an explanation of the various variables we refer to the notes to Table 5 and the following remarks:

- TAM stands for total of active measures. The following measures are active: labour market training (LMT), youth measures (YM), subsidised employment (SE), measures for the disabled (MD). PAS stands for total of passive measures. Unemployment compensation (UC) is one of these measures. The values of some countries are missing for the variables LMT, YM, SE, MD and UC;

- AUB is the average unemployment benefit (New Zealand is missing in the sample of noncorporatist countries)

- UNDR and UNDE are union density recorded and union density employed, respectively. 
Table $6.4^{a}$

Results for Calmfors \& Driffill's linear classification

\begin{tabular}{|c|c|c|c|}
\hline Variable & Mean-corp & Mean-non-corp & P-value \\
\hline \multicolumn{4}{|c|}{ Government Expenditures } \\
\hline EXP80 & 38.4 & 32.9 & 0.2947 \\
\hline EXP85 & 40.2 & 36.1 & 0.4794 \\
\hline EXP90 & 39.9 & 34.9 & 0.3570 \\
\hline \multicolumn{4}{|l|}{ Taxes } \\
\hline TAX70 & 36.8 & 29.1 & 0.0024 \\
\hline TAX75 & 40.5 & 31.1 & 0.0014 \\
\hline TAX80 & 42.9 & 33.1 & 0.0020 \\
\hline TAX85 & 44.3 & 35.3 & 0.0051 \\
\hline TAX90 & 44.9 & 36.4 & 0.0165 \\
\hline ATTR91 & 38.5 & 29.6 & 0.0901 \\
\hline MTTR91 & 51.4 & 41.8 & 0.1210 \\
\hline \multicolumn{4}{|c|}{ Labour Market Programmes } \\
\hline TAM85 & 0.98 & 0.65 & 0.2285 \\
\hline TAM90 & 1.05 & 0.63 & 0.0556 \\
\hline PAS85 & 1.39 & 1.61 & 0.696 \\
\hline PAS90 & 1.70 & 1.36 & 0.523 \\
\hline TAM/PAS85 & 0.94 & 0.49 & 0.1164 \\
\hline TAM/PAS90 & 0.80 & 0.59 & 0.3634 \\
\hline LMT85 & 0.23 & 0.18 & 0.6026 \\
\hline LMT90 & 0.34 & 0.20 & 0.1207 \\
\hline YM85 & 0.07 & 0.18 & 0.1672 \\
\hline YM90 & 0.09 & 0.14 & 0.4751 \\
\hline SE85 & 0.22 & 0.26 & 0.7475 \\
\hline SE90 & 0.15 & 0.14 & 0.9103 \\
\hline MD85 & 0.32 & 0.06 & 0.1021 \\
\hline MD90 & 0.34 & 0.08 & 0.0122 \\
\hline UC85 & 1.27 & 1.49 & 0.6822 \\
\hline UC90 & 1.43 & 1.29 & 0.755 \\
\hline AUB91 & 43.9 & 26.9 & 0.0257 \\
\hline \multicolumn{4}{|c|}{ Union Density } \\
\hline UNDR75 & 63.8 & 47.6 & 0.0527 \\
\hline UNDR80 & 68.6 & 48.6 & 0.0590 \\
\hline UNDR85 & 68.0 & 50.9 & 0.1327 \\
\hline UNDE75 & 56.2 & 41.9 & 0.0747 \\
\hline UNDE80 & 58.5 & 41.9 & 0.0754 \\
\hline UNDE85 & 57.3 & 38.4 & 0.0630 \\
\hline
\end{tabular}


Participation Rates

PART70 68.0

PART80 69.6

PART87 $\quad 69.4$

$\begin{array}{ll}\text { PART90 } & 75.1\end{array}$

FPART70 48.5

FPART80 57.3

FPART87 60.7

FPART90

67.0

65.8

0.4240

$65.1 \quad 0.1835$

$63.5 \quad 0.1833$

$\begin{array}{ll}70.8 & 0.2297\end{array}$

$43.2 \quad 0.2687$

$47.5 \quad 0.0685$

$51.2 \quad 0.1291$

$58.1 \quad 0.1162$ 
Table $6.6^{a}$

Results for Calmfors \& Driffill's parabolic classification

$\begin{array}{lll}\text { Variable Mean-mid } \quad \text { Mean-ext } & \text { P-value }\end{array}$

\section{Government Expenditures}

EXP85

42.5

32.8

32.7

0.0744

EXP90

39.5

0.1914

Labour Market Programmes

TAM85

0.80

0.74

0.8107

TAM90

0.79

0.81

0.98

0.9131

PAS85

2.03

1.36

0.0407

PAS90

1.63

0.6105

TAM/PAS85

0.47

0.85

0.1867

TAM/PAS90

0.52

0.83

0.1657

LMT85

0.19

0.21

0.8326

LMT90

0.24

0.28

0.6326

YM85

0.20

0.06

0.1107

YM90

0.17

0.08

0.1910

SE85

0.30

0.19

0.3707

SE90

0.17

0.13

0.7070

MD85

0.17

0.19

0.8581

MD90

0.14

0.410

UC85

1.93

UC90

1.57

0.89

0.013

1.15

0.3281

Participation Rates

PART70

PART80

PART87

FPART70

64.5

68.7

0.1141

62.5

60.0

40.5

FPART80

43.7

FPART87

47.2

71.2

0.0030

71.6

0.0026

50.1

0.0292

58.9

0.0014

62.6

0.0062 
